\title{
Original Article (short paper) \\ Motor abilities, activities, and participation of institutionalized Brazilian children and adolescents with cerebral palsy
}

\author{
Tainá Ribas Mélo ${ }^{1,2,3^{*}}$, Bruna Yamaguchi ${ }^{1}$, Adriano Zanardi da Silva ${ }^{1}$, Vera Lúcia Israel ${ }^{1}$ \\ ${ }^{1}$ Universidade Federal do Paraná, UFPR, Curitiba, PR, Brazil; ${ }^{2}$ Centro Universitário Campos de Andrade, \\ Uniandrade, Curitiba, PR, Brazil ;'Instituto Brasileiro de Therapias e Ensino, Curitiba, PR, Brazil
}

\begin{abstract}
Aim: To assess motor abilities and functioning of institutionalized children and adolescents with cerebral palsy (CP) within a contextual model of development. Methods: Eleven institutionalized Brazilian children and adolescents aged 2-19 $(14 \pm 5)$ years, 5 males and 6 females, were evaluated through the Gross Motor Function Measure (GMFM-88 and 66) and the Functional Independence Measure (FIM), and classified according to the ICF core set. Results: The evaluated individuals have severe impairments as indicated by their GMFM scores and confirmed by their need for full assistance in basic activities of daily living according to the FIM assessment. The difficulties manifested reflected on the ICF body functions and activities and participation domains. Conclusion: Most institutionalized children and adolescents with CP had GMFM-66 scores comparable to those indicated in literature. The ICF-based assessment identified environmental barriers that might be considered for improvement in order to facilitate activities and participation.
\end{abstract}

Keywords: cerebral palsy, International Classification of Functionality, disability and health, physical therapy specialty, institutionalized children; motor skills.

\section{Introduction}

Cerebral palsy (CP) is a lifelong, non-progressive encephalopathy with onset in infancy and early childhood, characterized by posture and movement disorders ${ }^{1,2}$. In most cases, the disorder manifests with muscle-tendon shortening and reduced range of motion ${ }^{3}$ while other cases entail a greater need for assistance in the activities of daily living (ADLs) ${ }^{4}$.

Studies have demonstrated that adolescents may experience developmental delays in some aspects of sensorimotor function, ${ }^{5}$ and that children with CP show a period of stability and subsequent decline in motor development between ages 2-21 years, especially for the most severe impairments regarding the GMFCS (Gross Motor Function Classification System)-levels IV and $\mathrm{V}^{6}$. Some GMFCS items are particularly useful to indicate motor delays ${ }^{4}$. Furthermore, associated cognitive impairments may contribute to that regression ${ }^{4}$.

Low socioeconomic status leads some poverty-stricken Brazilian families to abandon or lose custody of their children with $\mathrm{CP}^{7}$, especially those with more severe impairments ${ }^{8}$. Some of those children lacking family care are institutionalized for long periods, quite often for life ${ }^{9}$.

Institutionalized children have poorer motor development compared to their non-institutionalized peers. All young children residing in institutions are deprived of stimulation at early age, which results in fewer opportunities to enhance their neuronal circuitry ${ }^{10}$. For children with $\mathrm{CP}$, this lack of stimulation may have particularly serious consequences. In an ecological ${ }^{11,12}$ and contextual model of development, the environment ${ }^{13}$ of institutionalized children may be a limitation to their development.

At present, the World Health Organization (WHO) recommends that assessments should take into account not only issues related to body structures and functions but also environmental factors and activities and participation, as categorized in the entries of the International Classification of Functioning, Disability and Health (ICF) ${ }^{14,15}$. In the ICF model, both gross motor function and daily activities are encompassed by the "Activities" domain ${ }^{16}$.

The ICF conceptual framework is based on a biopsychosocial model comprising functioning and disability with their components, "Body Structures", "Body Functions", and "Activities and Participation", as well as a contextual part represented by personal and environmental factors ${ }^{17}$.

The postural impairments found among institutionalized Brazilian children have been described by Yamaguchi, de Souza, Pelloso, Villegas, Israel ${ }^{2}$, but the characterization of the motor profiles of children in long-stay institutions necessitates further research.

Clearly, the development patterns of the motor behaviors of children with CP vary according to the severity of the condition ${ }^{18}$. The Gross Motor Function Measure (GMFM-88 ${ }^{18}$ and GMFM-66 ${ }^{19}$ ) and the Gross Motor Function Classification System (GMFCS) are widely used, validated measures ${ }^{20}$ to describe gross motor development patterns of institutionalized children with CP. When combined, these measures, recommended by the ICF ${ }^{14}$, can identify percentiles of motor growth ${ }^{21}$. The responsiveness of the GMFM-66 is superior to that of the GMFM- $88^{19}$. Both GMFCS and GMFM have validated Brazilian versions with good reliability ${ }^{22,23}$.

The Functional Independence Measure (FIM) ${ }^{24}$ is a caregivercentered assessment of some ADLs performed by children and adolescents with $\mathrm{CP}^{25}$.

The Brazilian literature is still scarce regarding the use of 
ICF in institutionalized children, especially those with CP. The aim of the present study was to assess the motor abilities and functioning of institutionalized children and adolescents with $\mathrm{CP}$ within a contextual model of development, with the hypothesis of a negative impact of long-stay institutions, thus filling a gap in the literature in this area.

\section{Methods}

This cross-sectional observational study was conducted at a Brazilian research institution that shelters and provides care to more than 200 residents, mostly adults and older individuals, with a variety of conditions and types of disabilities. All children and adolescents with $\mathrm{CP}$ who were able to rise from bed independently or with assistance were evaluated, while those on mechanical ventilation were not included in the study. This investigation was approved by the Research Ethics Committee of the Instituto Brasileiro de Therapias e Ensino IBRATE (Brazilian Institute of Therapies and Teaching) under CAAE registry No. 53310116.8.0000.5229, clinical registration RBR-2st594.

For the purposes of the present study, "children" were defined as individuals under age of 10 and "adolescents" were those aged between $10-19$ years ${ }^{26}$.

Eleven institutionalized Brazilian children and adolescents ( 5 males, 6 females) aged 2-19 years (mean, $14 \pm 5$ years) were evaluated using dimensions A through D of the Brazilian version of the GMFM-88 (lying and rolling, crawling and kneeling, sitting, standing, and walk-run-jump activities) ${ }^{27}$. Scores for each item ranged from 0 (subject does not initiate the activity) to 3 (subject completes the activity), with intermediate scores ( 1 and 2) describing partial performance ${ }^{22}$.

The data were analyzed using the Gross Motor Ability Estimator (GMAE) to obtain a GMFM-66 score interval for each child ${ }^{16}$. Gross motor function was categorized using the GMFCS ${ }^{28}$. All participants had multiple impairments (intellectual, visual and/or physical).

The motor evaluations were conducted by three physical therapists. Scores were given by the therapist with 10 years' experience in the administration and scoring of GMFM- 88 and 6 years' experience with GMFM-66 scoring by GMAE.

The Brazilian version of the FIM ${ }^{24}$ was used in the assessment and observation of daily activities. Scores denoted the following: $7=$ complete independence; $6=$ modified independence requiring use of a device but no physical assistance; $5=$ supervision requiring only stand-by assistance or verbal prompting or help with setup; $4=$ minimal assistance, requiring incidental hands-on help only (subject performs $>75 \%$ of the task); $3=$ moderate assistance, subject still performs $50-75 \%$ of the task; $2=$ maximal assistance, subject provides less than half of the effort $(25-49 \%) ; 1=$ total assistance, subject contributes $<25 \%$ of the effort or is unable to do the task ${ }^{24}$.

The developmental history records of the children and adolescents were not available due to judicial secrecy given their institutionalization status. All children at the institution receive multi-professional health care (physiotherapy, occupational therapy, speech-language therapy). However, the frequency of sessions is reduced due to a low health professional/patient ratio.

Following the motor evaluations, the children and adolescents were classified according to the ICF ${ }^{29}$ core set, which provided the focus and domains. The ICF qualifiers for body functions, body structures, and activities and participation are as follows: $0=$ no problem; $1=$ mild problem; $2=$ moderate problem; $3=$ severe problem, and $4=$ complete problem. For environmental factors, the ICF qualifiers were the following: $0=$ no barrier/ facilitator; $+1=$ mild facilitator; $+2=$ moderate facilitator; +3 $=$ substantial facilitator; $+4=$ complete facilitator; $1=$ mild barrier; 2 = moderate barrier; $3=$ substantial barrier; $4=$ complete barrier ${ }^{30}$. All domains included qualifiers $8=$ not specified and $9=$ not applicable ${ }^{29}$.

The consistency of the present study has been corroborated by a number of studies, such as a systematic review ${ }^{31}$, showing that the GMFCS, GMFM, and FIM are adequate instruments to evaluate this population previously to an ICF-based assessment.

\section{Results}

Only one adolescent was able to walk independently, with GMFCS level II; GMFM-66 scores were lower than expected for this individual's age and GMFCS level. Most children were GMFCS level IV $(n=3 ; 27 \%)$ and V $(n=7 ; 63 \%)$, with limb distribution of either diplegia $(n=5 ; 45 \%)$ and quadriplegia (n $=6 ; 54 \%)$. Children with spastic $\mathrm{CP}(\mathrm{n}=10 ; 90 \%)$ spent most of their time in bed or in a non-customized wheelchair. One child had CP associated with West syndrome (Table 1).

Considering the heterogeneity of children with $\mathrm{CP}{ }^{16}$, the authors of the present study plotted the GMFM-66 mean for each individual (Table 1). In the graph (Figure 1), circles denote mean GMFM scores, the grayscale represents GMFCS levels, and the evaluated child/adolescent is identified by numbers.

The mean GMFM- 66 scores of most $(n=8 ; 72 \%)$ children are consistent with Hanna et al. ${ }^{6}$ GMFCS curves showing declining development. Three of the children (numbers 1, 7, and 9) had low scores for their age and GMFCS level.

The FIM (Table 2$)$ revealed that most $(n=10 ; 90 \%)$ children and adolescents were fully dependent for self-care, and all of them required total assistance with regard to sphincter control. Mobility and locomotion were compromised in most children. Communication and psychosocial factors were partial achievements for four children.

The difficulties evidenced by the GMFM and FIM had impact on the ICF body functions and activities and participation domains. Most children had severe movement control impairments, which reflected in fine hand use, toileting, and eating. Clearly, the health professionals at the institution represent an environmental factor of facilitation of health services. On the other hand, there was lack of some assistive equipment and technologies that could help the children and adolescents in their activities and participation.

For an overview of the results, see the diagram in Figure 2. 
Table 1. Results of the evaluation of children and adolescents with CP

\begin{tabular}{|c|c|c|c|c|c|c|c|c|c|c|c|}
\hline $\begin{array}{c}\text { Child/ } \\
\text { Adolescent }\end{array}$ & 1 & 2 & 3 & 4 & 5 & 6 & 7 & 8 & 9 & 10 & 11 \\
\hline Sex & female & male & female & female & female & female & male & female & male & male & male \\
\hline Age (years) & 18 & 19 & 18 & 16 & 15 & 15 & 11 & 18 & 14 & 9 & 2 \\
\hline $\begin{array}{l}\text { Clinical } \\
\text { diagnosis }\end{array}$ & $\mathrm{CP}$ & $\mathrm{CP}$ & $\mathrm{CP}$ & $\mathrm{CP}$ & $\mathrm{CP}$ & $\mathrm{CP}$ & $\mathrm{CP}$ & $\mathrm{CP}$ & $\mathrm{CP}$ & $\mathrm{CP}+\mathrm{WS}$ & $\mathrm{CP}$ \\
\hline $\begin{array}{l}\text { Distribution } \\
\text { of CP }\end{array}$ & diplegia & diplegia & diplegia & diplegia & quadriplegia & diplegia & quadriplegia & quadriplegia & quadriplegia & quadriplegia & quadriplegia \\
\hline Type of CP & spastic & spastic & spastic & spastic & spastic & spastic & spastic & spastic & spastic & athetoid & spastic \\
\hline GMFCS & II & IV & IV & IV & $\mathrm{V}$ & $\mathrm{V}$ & V & $\mathrm{V}$ & $\mathrm{V}$ & $\mathrm{V}$ & V \\
\hline $\begin{array}{l}\text { Impairment } \\
\text { types }\end{array}$ & $\begin{array}{l}\text { multiple } \\
(\mathrm{P}+\mathrm{I})\end{array}$ & $\begin{array}{l}\text { multiple } \\
(\mathrm{P}+\mathrm{I})\end{array}$ & $\begin{array}{l}\text { multiple } \\
(\mathrm{V}+\mathrm{P}+\mathrm{I})\end{array}$ & $\begin{array}{l}\text { multiple } \\
(\mathrm{P}+\mathrm{I})\end{array}$ & $\begin{array}{l}\text { multiple } \\
(\mathrm{P}+\mathrm{I})\end{array}$ & $\begin{array}{l}\text { multiple } \\
(\mathrm{V}+\mathrm{P}+\mathrm{I})\end{array}$ & $\begin{array}{l}\text { multiple } \\
(\mathrm{V}+\mathrm{P}+\mathrm{I})\end{array}$ & $\begin{array}{l}\text { multiple } \\
(\mathrm{P}+\mathrm{I})\end{array}$ & $\begin{array}{l}\text { multiple } \\
(\mathrm{V}+\mathrm{P}+\mathrm{I})\end{array}$ & $\begin{array}{l}\text { multiple } \\
(\mathrm{V}+\mathrm{P}+\mathrm{I})\end{array}$ & $\begin{array}{l}\text { multiple } \\
(\mathrm{V}+\mathrm{P}+\mathrm{I})\end{array}$ \\
\hline \multicolumn{12}{|l|}{$G M F M-88$} \\
\hline $\begin{array}{l}\text { A (lying } \\
\text { and rolling) }\end{array}$ & 72.55 & 84.31 & 72.55 & 37.25 & 37.25 & 35.29 & 11.76 & 35.29 & 7.84 & 21.57 & 1.96 \\
\hline $\begin{array}{l}\text { B } \\
\text { (crawling } \\
\text { and } \\
\text { kneeling) }\end{array}$ & 65.00 & 25.00 & 70.00 & 41.67 & 21.67 & 16.67 & 5.00 & 13.33 & 0.00 & 16.67 & 10.00 \\
\hline $\mathrm{C}$ (sitting) & 26.19 & 7.14 & 14.29 & 9.52 & 0.00 & 0.00 & 0.00 & 0.00 & 0.00 & 0.00 & 0.00 \\
\hline $\begin{array}{l}\text { D } \\
\text { (standing) }\end{array}$ & 48.72 & 0.00 & 0.00 & 0.00 & 0.00 & 0.00 & 0.00 & 0.00 & 0.00 & 0.00 & 0.00 \\
\hline $\begin{array}{l}\text { E (walk- } \\
\text { run-jump) }\end{array}$ & 33.33 & 0.00 & 0.00 & 0.00 & 0.00 & 0.00 & 0.00 & 0.00 & 0.00 & 0.00 & 0.00 \\
\hline Mean & 49.16 & 23.29 & 31.37 & 17.69 & 11.78 & 10.39 & 3.35 & 9.73 & 1.57 & 7.65 & 2.39 \\
\hline $\begin{array}{l}\text { GMFM-66 } \\
\text { (number of } \\
\text { items) }\end{array}$ & 54 & 66 & 54 & 65 & 66 & 66 & 66 & 65 & 66 & 66 & 66 \\
\hline Mean & 53.32 & 29.96 & 39.73 & 33.37 & 26.02 & 24.66 & 13.54 & 24.01 & 0 & 18.89 & 12.12 \\
\hline SD & 1.23 & 1.94 & 1.23 & 1.76 & 2 & 2 & 3 & 2 & 8.35 & 2.35 & 3.35 \\
\hline
\end{tabular}

$\mathrm{CP}=$ cerebral palsy; $\mathrm{WS}=$ West syndrome $\mathrm{P}=$ physical; $\mathrm{V}=$ visual; $\mathrm{I}=$ intellectual; $\mathrm{SD}=$ standard deviation

Figure 1. Distribution of the children and adolescents by age, GMFM66 means, and GMFCS level curves.

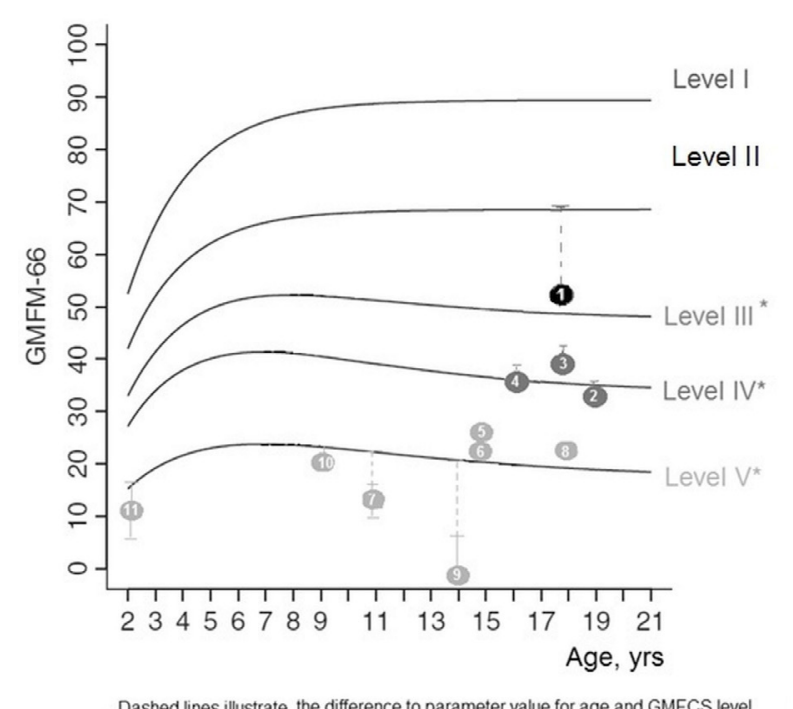

Dashed lines illustrate the difference to parameter value for age and GMFCS level
* Curves of GMFCS levels with significant average peak and decline(HANNA et al., 2009).

\section{Discussion}

Most institutionalized individuals evaluated in this study have severe impairments indicated by their GMFCS level and multiple impairments ${ }^{8}$, which are probably related to the high costs ${ }^{32}$ and difficulties in accessing health care services ${ }^{13}$, showing total dependence regarding $\mathrm{ADLs}^{33}$, as assessed by the FIM. Considering that Brazil is a resource-poor country with numerous long-term care institutions, studies addressing the influence of this setting on the development of this population of children and adolescents are warranted. Both poverty ${ }^{33}$ and severe disabilities ${ }^{34}$ may be risk factors for institutionalization of children with $\mathrm{CP}$ and require further investigation, which will help draw attention to those issues ${ }^{9}$. Children with $\mathrm{CP}$, depending on the extent of brain injury, will experience varying levels of limitations in $\mathrm{ADLs}^{35}$, especially when institutionalized.

The mean GMFM-66 of the children in this study is consistent with that reported by Hanna et al. ${ }^{6}$, who noted that children at GMFCS levels III-V have a peak of development by the age of 7 years old, with a subsequent decline. Adolescence is a transitional period that calls for attention, and is still an understudied field of knowledge ${ }^{36}$ with respect to evaluating 
different environments ${ }^{16}$. A systematic review ${ }^{31}$ has shown that studies of non-institutionalized children with CP had $88 \%$ of the GMFM categories focused on "activities and participation" above body functions, body structures, and environment, which are cornerstones of the ICF model. The differences between the systematic review and the present group of institutionalized children and adolescents were assessed; the severity of motor impairment was noticeably greater in the present study.

Table 2. Functional Independence Measure scores of institutionalized Brazilian children and adolescents with CP

\begin{tabular}{|c|c|c|c|c|c|c|c|c|c|c|c|c|}
\hline \multicolumn{2}{|c|}{ Functional Independence Measure } & \multirow{2}{*}{$\frac{1}{2}$} & \multirow{2}{*}{$\frac{2}{1}$} & \multirow{2}{*}{$\frac{3}{1}$} & \multirow{2}{*}{$\frac{4}{1}$} & \multirow{2}{*}{$\frac{5}{1}$} & \multirow{2}{*}{$\frac{6}{1}$} & \multirow{2}{*}{$\frac{7}{1}$} & \multirow{2}{*}{$\frac{\mathbf{8}}{1}$} & \multirow{2}{*}{$\frac{9}{1}$} & \multirow{2}{*}{$\frac{10}{1}$} & \multirow{2}{*}{$\frac{11}{1}$} \\
\hline & A- Eating & & & & & & & & & & & \\
\hline & B- Grooming & 1 & 1 & 1 & 1 & 1 & 1 & 1 & 1 & 1 & 1 & 1 \\
\hline & 3. Bathing/showering & 2 & 1 & 1 & 1 & 1 & 1 & 1 & 1 & 1 & 1 & 1 \\
\hline & 4. Dressing upper body & 2 & 1 & 1 & 1 & 1 & 1 & 1 & 1 & 1 & 1 & 1 \\
\hline & 5. Dressing lower body & 1 & 1 & 1 & 1 & 1 & 1 & 1 & 1 & 1 & 1 & 1 \\
\hline & 6. Toileting & 1 & 1 & 1 & 1 & 1 & 1 & 1 & 1 & 1 & 1 & 1 \\
\hline \multirow[t]{2}{*}{ Sphincters } & G- Bladder management & 1 & 1 & 1 & 1 & 1 & 1 & 1 & 1 & 1 & 1 & 1 \\
\hline & H- Bowel management & 1 & 1 & 1 & 1 & 1 & 1 & 1 & 1 & 1 & 1 & 1 \\
\hline \multirow{4}{*}{ Mobility } & Transfers & & & & & & & & & & & \\
\hline & I. Transfers: bed/chair/wheelchair & 6 & 2 & 1 & 1 & 1 & 1 & 1 & 1 & 1 & 1 & 1 \\
\hline & J. Transfers: toilet & 1 & 1 & 1 & 1 & 1 & 1 & 1 & 1 & 1 & 1 & 1 \\
\hline & K. Transfers: bathtub/shower & 1 & 1 & 1 & 1 & 1 & 1 & 1 & 1 & 1 & 1 & 1 \\
\hline \multirow[t]{2}{*}{ Locomotion } & L-Locomotion: walking/wheelchair & 5 & 1 & 1 & 1 & 1 & 1 & 1 & 1 & 1 & 1 & 1 \\
\hline & M- Locomotion: stairs & 4 & 1 & 1 & 1 & 1 & 1 & 1 & 1 & 1 & 1 & 1 \\
\hline \multirow[t]{3}{*}{ Communication } & N- Comprehension & 2 & 6 & 1 & 1 & 3 & 1 & 1 & 3 & 1 & 1 & 1 \\
\hline & O- Expression & 2 & 6 & 1 & 1 & 3 & 1 & 1 & 3 & 1 & 1 & 1 \\
\hline & P- Social Interaction & 2 & 2 & 1 & 1 & 2 & 1 & 1 & 2 & 1 & 1 & 1 \\
\hline \multirow[t]{2}{*}{ Psychosocial } & Q- Problem-solving & 1 & 3 & 1 & 1 & 1 & 1 & 1 & 1 & 1 & 1 & 1 \\
\hline & R- Memory & 1 & 1 & 1 & 1 & 1 & 1 & 1 & 1 & 1 & 1 & 1 \\
\hline
\end{tabular}

Table 3. ICF of institutionalized children and adolescents with CP

\begin{tabular}{|c|c|c|c|c|c|c|c|c|c|c|c|c|c|}
\hline \multicolumn{3}{|c|}{ Children/Adolescents } & 1 & 2 & 3 & 4 & 5 & 6 & 7 & 8 & 9 & 10 & 11 \\
\hline \multicolumn{3}{|l|}{ ICF } & \multicolumn{11}{|c|}{ Qualifiers } \\
\hline Structure Function & Structure of brain & s110 & 8 & 8 & 8 & 8 & 8 & 8 & 8 & 8 & 8 & 8 & 8 \\
\hline \multirow{5}{*}{ 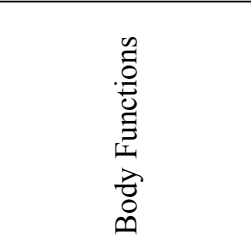 } & Intellectual function & b117 & 3 & 2 & 3 & 3 & 3 & 3 & 4 & 2 & 4 & 4 & 8 \\
\hline & Seeing function & $\mathrm{b} 210$ & 0 & 0 & 4 & 0 & 0 & 8 & 8 & 0 & 8 & 8 & 4 \\
\hline & Mobility of joint & b710 & 1 & 2 & 2 & 2 & 3 & 3 & 4 & 3 & 4 & 2 & 4 \\
\hline & Muscle tone functions & b735 & 1 & 2 & 2 & 2 & 2 & 3 & 4 & 3 & 4 & 3 & 4 \\
\hline & Control of voluntary movement functions & b760 & 1 & 2 & 2 & 2 & 3 & 3 & 4 & 3 & 4 & 4 & 4 \\
\hline \multirow{8}{*}{ 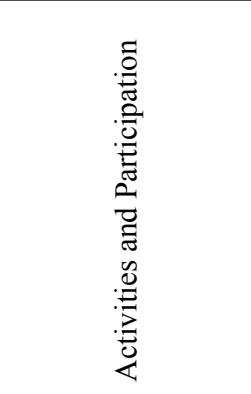 } & Maintaining a body position & $\mathrm{d} 415$ & 1 & 2 & 1 & 2 & 3 & 3 & 4 & 3 & 4 & 4 & 4 \\
\hline & Fine hand use & $\mathrm{d} 440$ & 1 & 3 & 3 & 3 & 4 & 4 & 4 & 4 & 4 & 4 & 4 \\
\hline & Walking & $\mathrm{d} 450$ & 1 & 4 & 4 & 4 & 4 & 4 & 4 & 4 & 4 & 4 & 4 \\
\hline & Moving around in different locations & $\mathrm{d} 460$ & 2 & 4 & 3 & 4 & 4 & 4 & 4 & 4 & 4 & 4 & 4 \\
\hline & Toileting & $\mathrm{d} 530$ & 4 & 4 & 4 & 4 & 4 & 4 & 4 & 4 & 4 & 4 & 4 \\
\hline & Eating & $\mathrm{d} 550$ & 3 & 2 & 4 & 4 & 3 & 4 & 4 & 3 & 4 & 4 & 4 \\
\hline & Basic interpersonal interactions & $\mathrm{d} 710$ & 2 & 1 & 3 & 4 & 3 & 3 & 4 & 4 & 4 & 4 & 4 \\
\hline & Family relationships & $\mathrm{d} 760$ & 4 & 4 & 4 & 4 & 4 & 4 & 4 & 4 & 4 & 4 & 4 \\
\hline \multirow{4}{*}{ 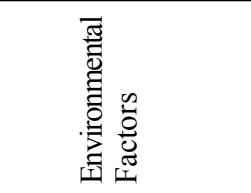 } & Products and technology for personal use in daily living & e115 & 1 & 3 & 4 & 4 & 4 & 4 & 4 & 4 & 4 & 4 & 8 \\
\hline & Products and technology for communication & $\mathrm{e} 125$ & 4 & 4 & 4 & 4 & 4 & 4 & 4 & 4 & 4 & 4 & 8 \\
\hline & Immediate family & e310 & 4 & 4 & 4 & 4 & 4 & 4 & 4 & 4 & 4 & 4 & 4 \\
\hline & Health services, systems, and policies & e580 & +4 & +4 & +4 & +4 & +4 & +4 & +4 & +4 & +4 & +4 & +4 \\
\hline
\end{tabular}


Figure 2- Characterization of institutionalized Brazilian children with CP by the ICF model

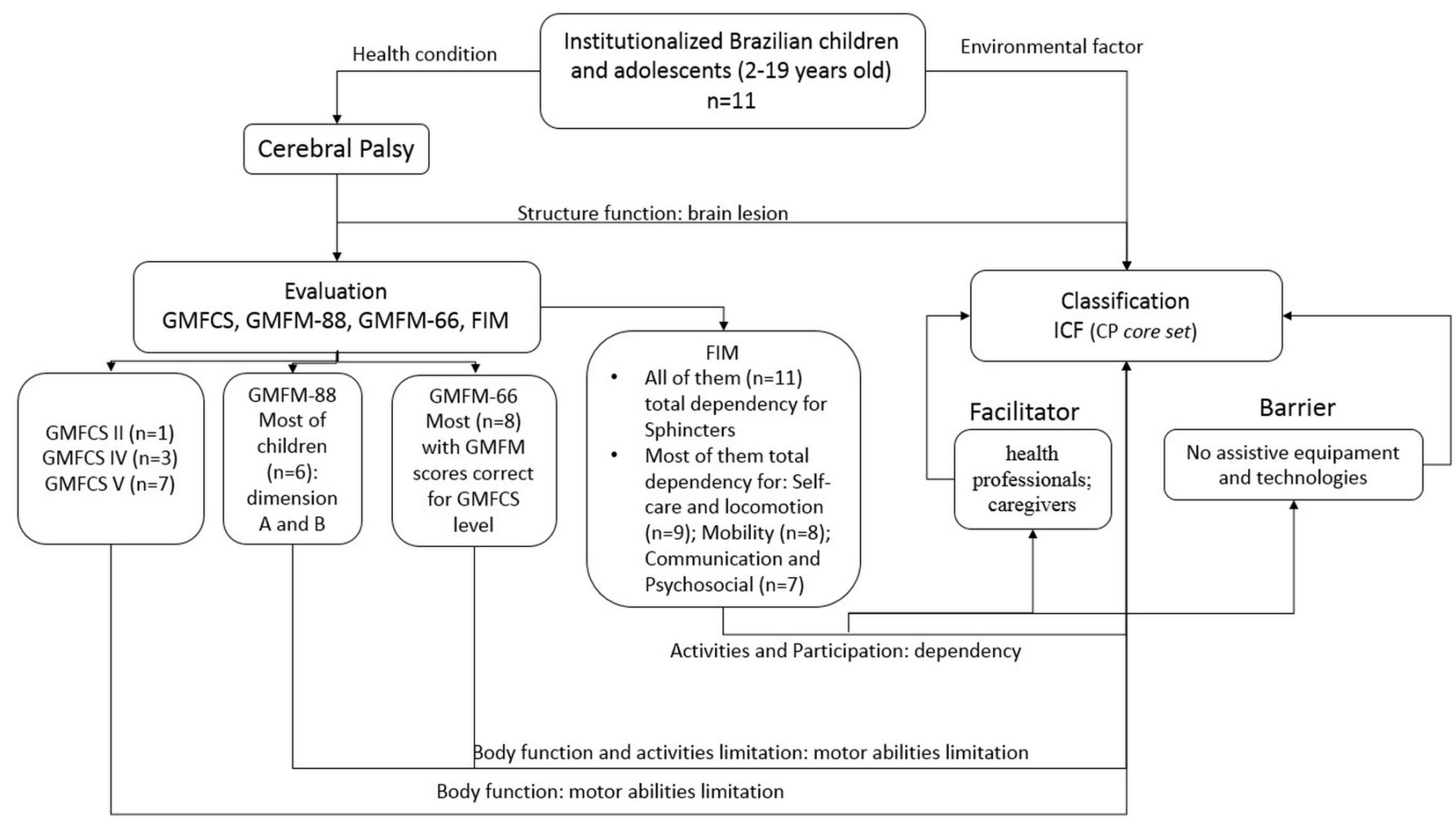

Environmental enrichment provides enhanced experiences for children and adolescents with $\mathrm{CP}$, thus constituting a positive factor for neurodevelopment and neuronal plasticity as it leads to increased neurotrophin synthesis and angiogenesis. Neuronal plasticity refers to structural and functional adaptations in the brain leading to improved function ${ }^{37}$.

In contrast to the present study, in the study of Huang, Tseng, Chen, Shieh, $\mathrm{Lu}^{38}$, most children with CP, were not at GMFCS levels IV and V. On the other hand, children at GMFCS level I had no difficulty performing activities in "Hygiene" and "Eating and Drinking" domains ${ }^{38}$, whereas participants of the present study were unable to perform those activities. Their current status could be the result of poor stimulation and inadequate daily positioning, which results in a high level of disability and, consequently, low ICF scores.

Despite the initial hypothesis of a negative influence of the long-term care institution caused by early deprivation and fewer opportunities to remodel neuronal circuits ${ }^{10}$, the present study showed motor development deterioration in consonance with the presentation described by Hanna et al. ${ }^{6}$, probably influenced by age and GMFCS level ${ }^{39}$. Only three children had low GMFM66 scores compared to peers of the same age and GMFCS level. It is not clear whether there was a negative influence of the environment on the children in our study based on their GMFM scores, since limitations in activities were significantly correlated with participation ${ }^{40}$. Arguably, those scores might not have been better, but their participation could be improved. The environmental barriers indicated by the ICF provide evidence of this, and might have impacted the motor abilities evaluated by the GMFM and the "Mobility and Self-care" domain of the FIM, with influence on the activities and participation components of the ICF. The children and adolescents at the institution had severe impairments in fine hand use (d440), compromising activities such as toileting (d530) and eating (d550). In fact, for Kwon, Yi, Kim, Chang, Kwon ${ }^{34}$ and Brandão, Ocarino, Bueno, Mancini ${ }^{41}$, hand use in CP is strongly related to self-care. Experimental studies with rats have shown that hand use increases the flow of nerve impulses in the dendrites, with remodeling of neuronal circuits after fine motor stimuli ${ }^{37}$. This is not possible for children with $\mathrm{CP}$, considering the brain damage and functional restriction caused by the condition.

The present study stands out for bringing to the fore the functionality of institutionalized children and adolescents. There is lack of other studies in the scientific literature with this population and their specificities.

Most children at the institution are dependent on caregivers, and daily activities are only stimulated during therapy sessions. Independent mobility is important for activities and participation as it reduces the burden on caregivers and the need for supportive environments. Children with significant mobility problems who cannot walk or get around independently are at risk of secondary related delays in additional mobility ${ }^{42,43}$, since early-onset muscle shortening and difficulty in breathing and swallowing reduce the chances of motor function and ADLs independence in adult life ${ }^{44}$.

Furthermore, with the exception of wheelchairs (all in need of repair), rehabilitation resources (e115; e120), such as orthoses and/or assistive technologies, are not used at the institution. The 
lack of those items constitutes complete barriers to most children.

The study by Bottos, Feliciangeli, Sciuto, Gericke, Vianello ${ }^{45}$ exposes need to focus on the functional status of persons with $\mathrm{CP}$, and suggests a more independence-oriented therapeutic approach as the most adequate to promote their functionality. The use of the ICF and FIM promotes a participatory vision in regard to persons with $\mathrm{CP}^{46}$, whether in self-care, daily life activities, or instrumental life activities.

A number of factors should be considered regarding the frequency of rehabilitation sessions ${ }^{47}$ For the weekly or bimonthly frequency modality, patients need to demonstrate continuous progress toward the established goals; the recommended frequency of sessions ranges from once to twice a week, and this does not seem to be the profile of the children and adolescents at the institution. For those showing a slow rate of achievement of goals in identified areas and/or do not regress on their motor abilities, frequency could be monthly ${ }^{47}$. By those recommendations, the children and adolescents are provided a minimum of motor rehabilitation (e580), which is a facilitator according to the ICF. Rehabilitation provides insights that promote neuronal plasticity, and it is thus a facilitator of development ${ }^{37}$.

Hoogsteen and Woodgate ${ }^{48}$ have established attributes of participation according to which children should take part in something or with someone, feel included, have a sense of control over what they are taking part in, and should also be working toward achieving a goal or enhancing their quality of life. This is not the case of the children evaluated in this study, considering their status of institutionalization.

In clinical practice, considering that the ICF-CY promotes family-centered care, the child's and their caregivers' opinions should be routinely addressed when setting goals for interventions. Working towards goals that are meaningful and relevant for both families and professionals might result in greater satisfaction and improved quality of life for all involved parties ${ }^{17}$.

Although the present study has demonstrated that most institutionalized children and adolescents with CP have severe impairment, the negative influence of this environment on their motor function is not clear. The GMFM-66 scores were close to those suggested by other authors. On the other hand, the ICFbased assessment identifies environmental barriers, such as the use of technologies, which could be considered for improvement in order to facilitate activities and participation.

Despite some limitations found in the present study, it seems to be the first to address motor function in institutionalized children and adolescents with cerebral palsy.

\section{Conclusion}

The GMFM and FIM instruments appear to be useful in the ICF model to assess the motor abilities and functioning of children and adolescents in long-term care institutions. Many of those institutions are devoted to the rehabilitation of children with $\mathrm{CP}$, which emphasizes body functions and structures. Currently, however, the analysis, classification, and even interventions on (or modification of) environmental factors not to mention the engagement of participants are inseparable components of the contextual perspective advocated by the WHO.

In view of the above considerations, the authors of the present study suggest further research, such as an assessment of the quality of life and ADLs in institutional environments and longitudinal investigations. One measure alone does not fully reflect the ICF, but a combination of measures seems more appropriate if the goal is to encompass all ICF components.

It should be highlighted that the ICF enabled an assessment of the functional and environmental restrictions of institutionalized children with $\mathrm{CP}$ and could be replicated in other places for comparisons and to elicit debate on how to intervene positively in the functionality of individuals.

\section{References}

1. Bax M, Goldstein M, Rosenbaum P, Leviton A, Paneth N, Dan $\mathrm{B}$, et al. Proposed definition and classification of cerebral palsy, April 2005. Dev Med Child Neurol. 2005;47(08):571-6.

2. Yamaguchi B, de Souza FCF, Pelloso IL, Villegas ISG, Israel VL. Efeito postural agudo da fisioterapia aquática na encefalopatia crônica não progressiva da infância. Rev Neurocienc. 2015;23(1):130-5.

3. Mélo TR, Rodacki ALF, Guimarães ATB, Israel VL. Repeatability and comparison of clinical tests in children with spastic diplegia and with typical development. Fisioter Mov. 2015;28(1):13-22.

4. Voorman JM, Dallmeijer AJ, Knol DL, Lankhorst GJ, Becher JG. Prospective longitudinal study of gross motor function in children with cerebral palsy. Arch Phys Med Rehabil. 2007 Jul;88(7):8716. PubMed PMID: 17601467. Epub 2007/07/03. eng.

5. Quatman-Yates CC, Quatman CE, Meszaros AJ, Paterno MV, Hewett TE. A systematic review of sensorimotor function during adolescence: a developmental stage of increased motor awkwardness? Br j sports med. 2012;46(9):649-55.

6. Hanna SE, Rosenbaum PL, Bartlett DJ, Palisano RJ, Walter SD, Avery L, et al. Stability and decline in gross motor function among children and youth with cerebral palsy aged 2 to 21 years. Dev Med Child Neurol. 2009 Apr;51(4):295-302. PubMed PMID: 19391185. Epub 2009/04/25. eng.

7. Cavalcante LIC, Magalhães CMC, Pontes FAR. Processos de saúde e doença entre crianças institucionalizadas: uma visão ecológica. Ciênc \& Saúde Coletiva. 2009;14(2):614-25.

8. Rizzini I, Almeida NC. A institucionalização de crianças e adolescentes com deficiência: anotações para uma agenda de política pública. Rev Saúde \& DH, FIOCRUZ. 2011 (7):159-77.

9. Queiroz M, Rizzini I. A infância com deficiência institucionalizada e os obstáculos históricos na defesa de seus direitos. O Social em Questão. 2012;Ano XV(28):199-220.

10. Levin AR, Zeanah CH, Fox NA, Nelson CA. Motor outcomes in children exposed to early psychosocial deprivation. The $\mathrm{J}$ of pediatrics. 2014;164(1):123-9. e1.

11. Poletto M, Koller SH. Contextos ecológicos: promotores de resiliência, fatores de risco e de proteção. Estud psicol. 2008;25(3):405-16. 
12. Ahl LE, Johansson E, Granat T, Carlberg EB. Functional therapy for children with cerebral palsy: an ecological approach. Dev Med Child Neurol. 2005;47(9):613-9.

13. Silva F, Sampaio RF, Ferreira FR, Camargos VP, Neves JA. Influence of context in social participation of people with disabilities in Brazil. Rev Pan de Salud Pública. 2013;34(4):250-6.

14. Dornelas LdF, Lambertucci MS, de Lima Mello M, Deloroso FT. Aplicabilidade da Classificação Internacional de Funcionalidade, Incapacidade e Saúde (CIF) para a avaliação de crianças com paralisia cerebral: uma revisão sistemática/Applicability of the International Classification of Functioning, Disability and Healt. Cad Ter Ocup UFSCar. 2014;22(3).

15. Gannotti ME, Christy JB, Heathcock JC, Kolobe TH. A path model for evaluating dosing parameters for children with cerebral palsy. Phys Ther. 2014;94(3):411-21.

16. Smits D-W, Gorter JW, Ketelaar M, Van Schie PE, Dallmeijer AJ, Lindeman E, et al. Relationship between gross motor capacity and daily-life mobility in children with cerebral palsy. Dev Med Child Neurol. 2010;52(3):e60-e6.

17. Schiariti V, Mâsse LC. Identifying relevant areas of functioning in children and youth with Cerebral Palsy using the ICF-CY coding system: From whose perspective? Eur J Paediatr Neurol. 2014;18(5):609-17.

18. Rosenbaum PL, Walter SD, Hanna SE, Palisano RJ, Russell DJ, Raina P, et al. Prognosis for gross motor function in cerebral palsy: creation of motor development curves. Jama. 2002;288(11):1357-63.

19. Russell DJ, Avery LM, Walter SD, Hanna SE, Bartlett DJ, Rosenbaum PL, et al. Development and validation of item sets to improve efficiency of administration of the 66-item Gross Motor Function Measure in children with cerebral palsy. Dev Med Child Neurol. 2010. Feb;52(2):e48-54. PubMed PMID: 19811516. Epub 2009/10/09. eng.

20. Palisano RJ, Hanna SE, Rosenbaum PL, Russell DJ, Walter SD, Wood EP, et al. Validation of a model of gross motor function for children with cerebral palsy. Phys Ther. 2000;80(10):974-85.

21. Hanna SE, Bartlett DJ, Rivard LM, Russell DJ. Reference curves for the Gross Motor Function Measure: percentiles for clinical description and tracking over time among children with cerebral palsy. Phys Ther. 2008 May;88(5):596-607. PubMed PMID: 18339799. Pubmed Central PMCID: 2390723. Epub 2008/03/15. eng.

22. Almeida KM, Albuquerque KA, Ferreira ML, Aguiar SK, Mancini MC. Reliability of the Brazilian Portuguese version of the Gross Motor Function Measure in children with cerebral palsy. Braz J phys ther. 2016 (AHEAD):0-.

23. Hiratuka E, Matsukura TS, Pfeifer LI. Cross-cultural adaptation of the gross motor function classification system into BrazilianPortuguese (GMFCS). Braz J phys ther. 2010;14(6):537-44.

24. Riberto M, Miyazaki MH, Jorge Filho D, Sakamoto H, Battistella LR. Reprodutibilidade da versão brasileira da Medida de Independência Funcional. Acta fisiátrica. 2001;8(1):45-52.

25. Sposito MMDM, Riberto M. Avaliação da funcionalidade da criança com Paralisia Cerebral espástica. Acta fisiátrica. 2010;17(2).

26. OMS-Organización Mundial de La Salud. La salud de los jóvenes: un reto y una esperanza. Genebra; 1995.
27. Rosenbaum P, Stewart D. The World Health Organization International Classification of Functioning, Disability, and Health: a model to guide clinical thinking, practice and research in the field of cerebral palsy. Semin Pediatr Neurol. 2004 Mar;11(1):510. PubMed PMID: 15132248. Epub 2004/05/11. eng.

28. Palisano RJ, Rosenbaum P, Bartlett D, Livingston $\mathrm{MH}$. Content validity of the expanded and revised Gross Motor Function Classification System. Dev Med Child Neurol. 2008;50(10):744-50.

29. OMS. CIF: Classificação Internacional de Funcionalidade, Incapacidade e Saúde. São Paulo: EDUSP.; 2015.

30. Schiariti V, Selb M, Cieza A, O’Donnell M. International Classification of Functioning, Disability and Health Core Sets for children and youth with cerebral palsy: a consensus meeting. Dev Med Child Neurol. 2015;57(2):149-58.

31. Schiariti V, Klassen AF, Cieza A, Sauve K, O’Donnell M, Armstrong R, et al. Comparing contents of outcome measures in cerebral palsy using the international classification of functioning (ICF-CY): A systematic review. Eur J Paediatr Neurol. 2014;18(1):1-12.

32. Eunson P. The long-term health, social, and financial burden of hypoxic-ischaemic encephalopathy. Dev Med Child Neurol. 2015;57(S3):48-50.

33. Assis-Madeira EA, Carvalho SG, Blascovi-Assis SM. Functional performance of children with cerebral palsy from high and low socioeconomic status. Rev Paul Pediatr. 2013;31(1):51-7.

34. Kwon TG, Yi S-H, Kim TW, Chang HJ, Kwon J-Y. Relationship between gross motor function and daily functional skill in children with cerebral palsy. Annals of rehabilitation medicine. 2013;37(1):41-9.

35. Lee B-H, Kim Y-M, Jeong G-C. Mediating effects of the ICF domain of function and the gross motor function measure on the ICF domains of activity, and participation in children with cerebral palsy. J Phys Ther Sci. 2015;27(10):3059.

36. Williams J. Children with disability grow into adults with a disability. Dev Med Child Neurol. 2008;50(3):163.

37. Johnston MV. Plasticity in the developing brain: implications for rehabilitation. Developmental disabilities research reviews. 2009;15(2):94-101.

38. Huang C-Y, Tseng M-H, Chen K-L, Shieh J-Y, Lu L. Determinants of school activity performance in children with cerebral palsy: A multidimensional approach using the ICF-CY as a framework. RES DEV DISABIL. 2013;34(11):4025-33.

39. Shevell MI, Dagenais L, Hall N. The relationship of cerebral palsy subtype and functional motor impairment: a population-based study. Dev Med Child Neurol. 2009 Nov;51(11):872-7. PubMed PMID: 19416339. Epub 2009/05/07. eng.

40. Park E-Y, Kim W-H. Relationship between activity limitations and participation restriction in school-aged children with cerebral palsy. J Phys Ther Sci. 2015;27(8):2611.

41. Brandão M, Ocarino JM, Bueno KMP, Mancini MC. Hand Use at Home and in Clinical Settings by Children with Cerebral Palsy: A Qualitative Study. Occup ther int. 2015;22(1):43-50.

42. Diwan S, Diwan J, Bansal AB, Patel PR. Changes in Capacity and Performance in Mobility Across Different Environmental Settings in Children with Cerebral Palsy: An Exploratory Study. J Clin Dia Res. JCDR. 2015;9(8):YC01. 
43. Ribeiro MFM, Vandenberghe L, Prudente COM, Vila VdSC, Porto CC. Paralisia cerebral: faixa etária e gravidade do comprometimento do filho modificam o estresse e o enfrentamento materno. Rev Ciência \& Saúde Coletiva. 2016;21(10).

44. Miyazaki Y, Iwai K, Matumura S, Miwa T, Yanagisako Y, Yanagi $\mathrm{H}$, et al. Serial changes in independent sitting in adults with severe cerebral palsy. Int J Clin Dia Res. 2004;27(3):233-5.

45. Bottos M, Feliciangeli A, Sciuto L, Gericke C, Vianello A. Functional status of adults with cerebral palsy and implications for treatment of children. Dev Med Child Neurol. 2001;43(8):516-28.

46. Silva AZd, Vojciechowski AS, Mélo TRM, Yamaguchi BY, Touchan AS, Bertoldi AS, et al. Avaliação neuropsicomotora e classificação funcional em escolares de 10 a 12 anos da rede pública. Rev Ter Ocup Univ São Paulo. 2016 (1):52-62. Epub jan.-abr.

47. Bailes AF, Reder R, Burch C. Development of guidelines for determining frequency of therapy services in a pediatric medical setting. Pediat Phys Ther. 2008;20(2):194-8.

48. Hoogsteen L, Woodgate RL. Can I play? A concept analysis of participation in children with disabilities. Phys occup ther pediat. 2010;30(4):325-39.

\section{Corresponding author}

*Tainá Ribas Mélo, PT, Msc.

Rua Coração de Maria, number 92, Campus Jardim Botânico, Curitiba, Paraná, Brazil.

Email: ribasmelo@gmail.com

Manuscript received on March 11, 2017

Manuscript accepted on May 07, 2017

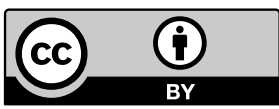

Motriz. The Journal of Physical Education. UNESP. Rio Claro, SP, Brazil - eISSN: 1980-6574 - under a license Creative Commons - Version 3.0 